\title{
Primary Lymphoepithelioma-Like Carcinoma of the Lung: Report of a Rare Case and Review of the Literature
}

\author{
Akciğerin Lenfoepitelyoma Benzeri Karsinomu: Nadir Bir Olgu \\ Eşliğinde Literatürün Gözden Geçirilmesi
}

\author{
Neşe Arzu YENER ${ }^{1}$, Ahmet BALIKÇI' ${ }^{2}$, Rahmi ÇUBUK ${ }^{3}$, Ahmet Midi ${ }^{1}$, Alpay ÖRKi ${ }^{4}$, Aynur EREN TOPKAYA ${ }^{2}$
}

Departments of ${ }^{1}$ Pathology, ${ }^{2}$ Microbiology, ${ }^{3}$ Radiology and ${ }^{4}$ Chest Surgery, Maltepe University, Faculty of Medicine, iSTANBUL, TURKEY

\begin{abstract}
Primary lymphoepithelioma-like carcinoma of the lung is a rare type of non-small cell lung carcinoma. In this study, we aimed to present a 62-year-old smoker male with a primary lymphoepithelioma-like carcinoma of the hilar region of the left lung. The patient underwent left pneumonectomy and no adjuvant therapy was given. There were no other abnormalities on whole body PET/CT scan including the nasopharyngeal region. The patient showed seropositivity for EBV IgG but immunohistochemistry and PCR amplification studied on paraffin-embedded tissue sections of the tumor failed to show any sign of EBV infection within the tumor cells. He is alive and disease-free four months after the operation. Although primary lymphoepithelioma-like carcinoma of the lung is usually reported in young females with no history of tobacco use and the tumor cells are infected with EBV, it may rarely be seen in elderly males with a history of tobacco use and the tumor cells not infected with EBV.
\end{abstract}

Key Words: Epstein-Barr virus, Carcinoma, Lymphoepitheliomalike, Lung cancer

\begin{abstract}
ÖZ
Akciğerin primer lenfoepitelyoma benzeri karsinomu, nazofarinkste görülen ile benzer klinik ve histopatolojik özellikler taşıyan, nadir bir küçük hücreli dışı akciğer karsinomu varyantıdır. Bu çalışmada, sol akciğer hiler yerleşimli kitlesi olan, uzun yıllardır sigara kullanma öyküsü bulunan, altmış iki yaşındaki erkek hastayı sunmayı amaçladık. Bronkoskopik biyopsisinde küçük hücreli dışı karsinom tanısı verilen hastanın pnömonektomi materyalinde lezyonun tamamının incelenmesi sonucu olgu, lenfoepitelyoma benzeri karsinom olarak rapor edildi. Hastanın, serolojik incelemesinde EBV IgG pozitif idi ancak tümöre ait parafin blokta yapılan immunohistokimyasal ve PCR çalışmaları ile tümör hücrelerinde EBV enfeksiyonu bulgusu saptanmadi. Nazofarinksi de kapsayan tüm vücut PET/ CT taramasında başka bir patoloji saptanmayan hasta, primer akciğer lenfoepitelyoma benzeri karsinomu olarak kabul edildi. Hastaya adjuvan tedavi verilmedi. Dördüncü ay izleminde nüks ya da metastaz bulgusu saptanmadi. Akciğerin primer lenfoepitelyoma benzeri karsinomu genelde diğer akciğer karsinomu türlerine göre daha genç, sigara öyküsü olmayan bayan hastalarda görülen ve EBV ile ilişkisi olduğu düşünülen bir tümör olmakla birlikte nadiren de bizim olgumuzdaki gibi daha yaşl, sigara kullanan erkek hastalarda ve EBV ile ilişkisiz olarak da görülebilir.
\end{abstract}

Anahtar Sözcükler: Epstein-Barr virüsü, Karsinom, Lenfoepitelyoma benzeri, Akciğer kanseri

\section{INTRODUCTION}

Primary lymphoepithelioma-like carcinoma (LELC) has been described in many organs such as the stomach, thymus, skin, liver, cervix, and urinary bladder. LELC originating from the lung was first described by Begin et al in 1987 (1). It preferentially affects non-smoker Asian patients of young age and is thought to have a better prognosis than the other types of non-small cell lung carcinomas $(2,3)$. Caucasian patients are more rarely affected $(2,4)$. In this study, we aimed to present a rare case of primary LELC of the lung in an elderly smoker male and review the relevant literature on this rare tumor.

\section{CASE REPORT}

A 62-year-old man with a 40 pack-year history of smoking applied to our hospital with complaints of cough and dyspnea for the last six months. He had a history of undergoing coronary artery by-pass surgery three months ago that had resulted in no relief of his symptoms. On chest computerized tomography (CT) imaging, a hilar mass of 2

Correspondence: Neșe Arzu YENER

Department of Pathology, Maltepe University, Faculty of Medicine, İSTANBUL, TURKEY

E-mail: nese.yener@yahoo.com Phone: +90 5053898454 
$\mathrm{cm}$ in size with lobulated margins located $1.5 \mathrm{~cm}$ distal to the bifurcation of the trachea was observed (Figure 1A). At retrospective evaluation of the baseline radiograph which had been obtained soon before his coronary artery bypass operation, the mass was seen as a nodule of less than $5 \mathrm{~mm}$ in diameter.

Fiberoptic bronchoscopy revealed a polypoid tumoral mass and the bronchus biopsy specimen was reported as "non-small cell carcinoma". The patient then underwent whole body imaging including the nasopharyngeal region (Figure 1B) but no other lesions or lymphadenomegaly was identified throughout the body. The patient underwent left pneumonectomy with nodal staging at the time. Frozen sections revealed nonmetastatic mediastinal lymph nodes. His postoperative course was uneventful.

On gross examination of the specimen, a relatively wellcircumscribed solid mass located in the right main bronchus was observed. On microscopic examination, the tumor consisted of uncircumscribed solid nests with the typical syncytial growth pattern. The tumor cells were undifferentiated epithelial cells with oval and pleomorphic nuclei. They had vesicular chromatin with distinct nucleoli. There were no apparent areas of necrosis and the mitotic count was variable (8/10 HPF). A significant lymphoplasmacytic infiltration within and around the tumor cells was also observed (Figure 2A, B). Immunohistochemically, tumor cells were positive for pancytokeratin and negative for latent membrane protein of EBV. The lymphocytes infiltrating the tumor cells were almost exclusively positive for $\mathrm{CD} 8$, whereas the rest of them were positive for CD20. EBV serology revealed positivity for EBV IgG, which suggested a prior infection. However, the tumor cells were negative for EBV DNA with PCR amplification.
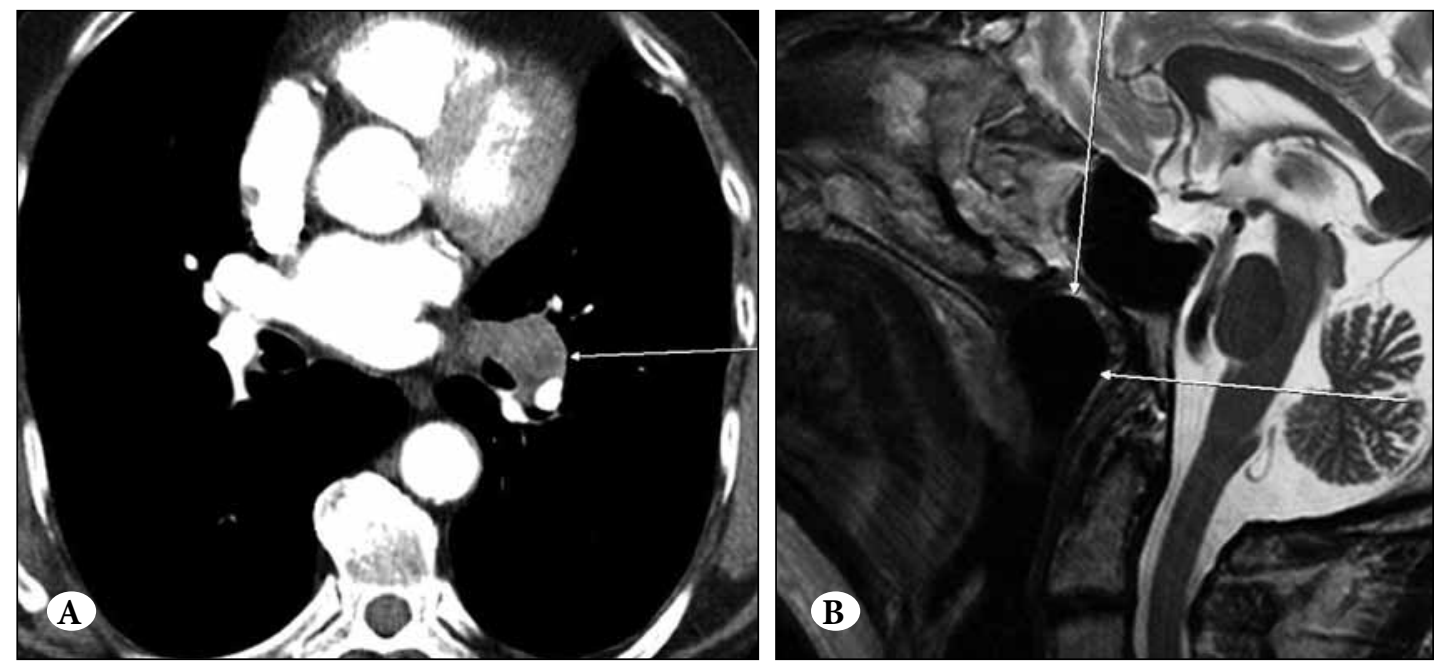

Figure 1: (A) CT scan revealed a large mass in the hilar region of the left lung, (B) and the head and neck region was negative for any nasopharyngeal lesions.
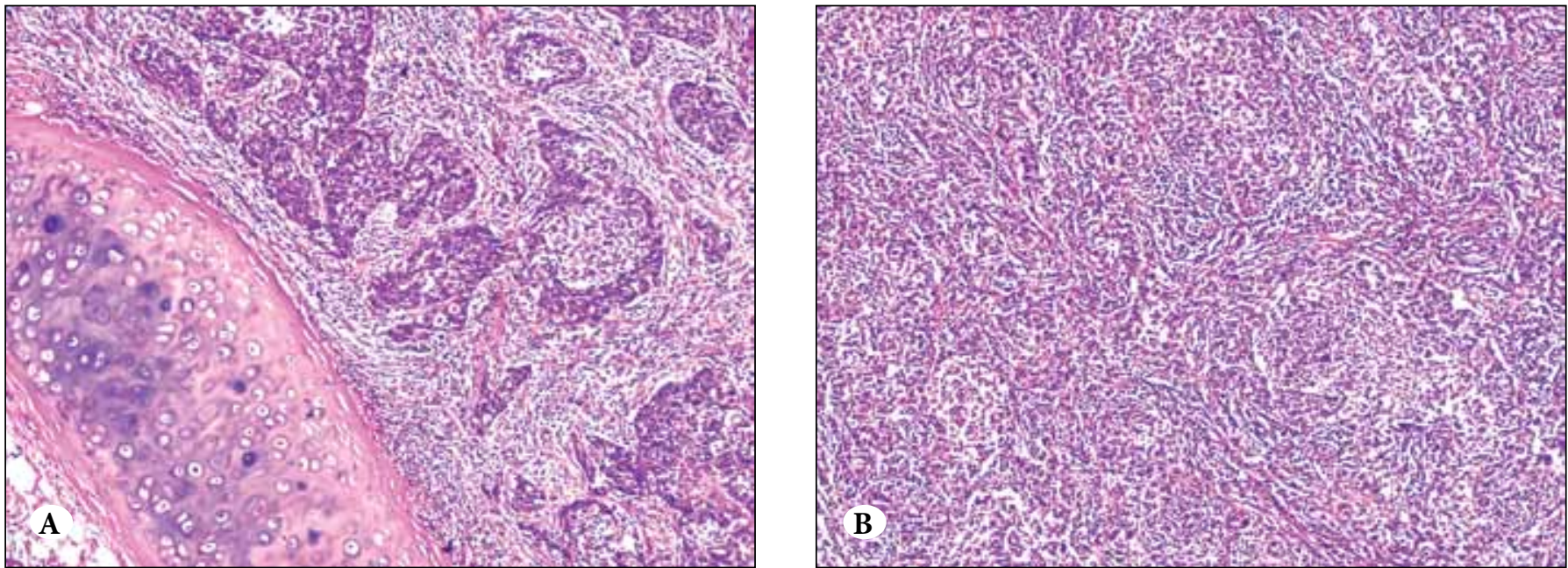

Figure 2A, B: Irregular solid epithelial cell islands infiltrated by dense lymphoplasmacytic infiltration (H\&E, x100). 
A final diagnosis of primary LELC of the lung was made with these findings. He was not given any adjuvant therapy. $\mathrm{He}$ is doing well and a standard chest radiograph revealed no evidence of recurrent disease at the fourth month of follow-up.

\section{DISCUSSION}

The commonest site of involvement for LELC is the nasopharynx where it is almost invariably associated with EBV infection. Primary LELC of the lung is a rare type of non-small cell lung cancer and it comprises about $0.9 \%$ of the other types of lung cancer (5). To recognize it as having a pulmonary origin, careful examination of the nasopharyngeal region should be done to exclude any primary nasopharyngeal tumor (2,5-7). LELC is a distinct type of non-small cell lung carcinoma in many aspects. It commonly affects patients younger than those typically affected by bronchogenic carcinoma (7). A female sex predilection was notified in several reports $(5,7,8)$ whereas not in the others $(2,6)$. It has no strong association with smoking $(2,5,8)$. EBV infection of the tumor is variable, and still much stronger in Asians than in whites $(2,5,6,8)$. The patients usually present at an early stage of the disease (2). Our case was a 62-year-old smoker nonAsian (Turkish) man with the disease at stage I (T1N0M0) and with serological evidences of a former EBV infection. However, the percentage of seroprevalance for EBV is about $95 \%$ in adults irrespective of country (9). Although DNA degradation in paraffin-embedded tissues may obscure the results of PCR amplification results (10), there was no evidence of EBV particles within the tumor cells in our case and we still consider that an unknown carcinogenic agent possibly related to tobacco use may play a role in the formation of LELC of pulmonary origin.

Radiographic, CT and MRI features of the primary pulmonary LELC at an early stage are reported as nonspecific (7). The characteristic CT findings in advanced stage disease are the central location of the tumor with welldefined, smooth borders and with variable dimensions (11). Peribronchovascular lymph node involvement and vascular encasement were also considered to be specific CT features for advanced stage LELC (11). Our case was at an early stage and CT findings were suggestive of any type of lung malignancy without any LELC-specific feature.

Histopathologically, the tumor is identical to its nasopharyngeal counterpart and it is characterized by two patterns of tumor growth as well-defined epithelial nests separated by broad areas of lymphocytic reaction and a diffuse infiltration of malignant epithelial cells infiltrated with non neoplastic lymphocytes (3). Lymphocytes infiltrating the tumor cells may represent the enhanced immunity, suggesting a better prognostic indicator (12). In our case, we observed these two patterns, mainly the welldefined nests of malignant epithelial cells. The abundant lymphocytes infiltrating the tumor cells forming these nests were of the $\mathrm{T}$ cell phenotype.

The mainstay of the treatment for LELC of the lung is surgery (2,3,5-7). Adjuvant chemotherapy or radiotherapy may be added especially in patients in advanced stage disease (13). Similarly, palliative chemotherapy and/or radiotherapy should be employed in patients with unresectable lesions (14). Given the rarity of primary LELC of the lung, the choice of chemotherapy treatment remains empirical (14). Based on the long term follow-up of the cases reported in the literature, the patients with LELC of the lung at an early stage seems to have a more favorable prognosis than do patients with other types of non-small cell carcinoma of similar stage $(3,6-8)$.

In conclusion, as a rare type of non-small cell lung cancer, primary LELC of the lung should be kept in mind even in nonendemic areas for EBV. Nasopharyngeal region as a possible primary site of origin should be ruled out before considering the tumor as primary lung origin.

\section{REFERENCES}

1. Begin LR, Eskandari J, Joncas J, Panasci L: Epstein-Barr virus related lymphoepithelioma-like carcinoma of the lung. J Surg Oncol 1987, 36:280-283

2. Chan JK, Hui PK, Tsang WY, Law CK, Ma CC, Yip TT, Poon YF: Primary lymphoepithelioma-like carcinoma of the lung. A clinicopathologic study of 11 cases. Cancer 1995, 76:413-422

3. Han A, Xiong M, Gu Y, Lin S, Xiong M: Lymphoepithelioma-like carcinoma of the lung with a better prognosis. A clinicopathologic study of 32 cases. Am J Clin Pathol 2001, 115:841-850

4. Bildirici K, Ak G, Peker B, Metintas M, Alatas F, Erginel S, Ucgun I: Primary lymphoepithelioma-like carcinoma of the lung. Tuberk Toraks 2005, 53: 69-73

5. Chang YL, Wu CT, Shih JY, Lee YC: New aspects in clinicopathologic and oncogene studies of 23 pulmonary lymphoepithelioma-like carcinomas. Am J Surg Pathol 2002, 26:715-723

6. Castro CY, Ostrowski ML, Barrios R, Green LK, Popper HH, Powell S, Cagle PT, Ro JY: Relationship between Epstein-Barr virus and lymphoepithelioma-like carcinoma of the lung: A clinicopathologic study of 6 cases and review of the literature. Hum Pathol 2001, 32:863-872

7. Hoxworth JM, Hanks DK, Araoz PA, Elicker BM, Reddy GP, Webb WR, Leung JW, Gotway MB: Lymphoepithelioma-like carcinoma of the lung: radiologic features of an uncommon primary pulmonary neoplasm. AJR 2006, 186:1294-1299 
8. Yoshino N, Kubokura H, Yamauchi S, Ohaki Y, Koizumi K, Shimizu K: Lymphoepithelioma-like carcinoma of the lung; case in which the patient has been followed up for 7 years postoperatively. Jpn J Thorac Cardiovasc Surg 2005, 53:653-656

9. Ozkan A, Kilic SS, Kalkan A, Ozden M, Demirdag K, Ozdarendeli A: Seropositivity of Epstein-Barr virus in Eastern Anatolian Region of Turkey. Asian Pac J Allergy Immunol 2003, 21:49-53

10. Charef S, Jrad BB, Mahfouth W, Zakhama A, Kassab A, Driss $N$, Chouchane L: Detection of EBV by PCR in fresh and paraffin embedded samples of cavum tumour. Arch Inst Pasteur Tunis 2006, 83:41-47 (abstract)

11. Ooi GC, Ho JC, Khong PL, Wang MP, Lam WK, Tsang KW: Computed tomography characteristics of advanced primary pulmonary lymphoepithelioma-like carcinoma. Eur Radiol 2003, 13:522-526
12. Kobayashi M, Ito M, Sano K, Honda T, Nakayama J: Pulmonary lymphoepithelioma-like carcinoma: Predominant infiltration of tumor-associated cytotoxic T lymphocytes might represent the enhanced tumor immunity. Intern Med 2004, 43:323-326

13. Chan ATC, Teo PML, Lam KC, Chan WY, Chow JHS, Yim APC, Mok TSK, Kwan WH, Johnson PJ: Multimodality treatment of primary lymphoepithelioma-like carcinoma of the lung. Cancer 1998, 83:925-929

14. Ho JC, Lam WK, Wong MP, Wong MK, Ooi GC, Chan-Yeung M, Tsang KW: Lymphoepithelioma-like carcinoma of the lung: Experience with ten cases. Int J Tuberc Lung Dis 2004, 8:890-895 